\title{
SIGNIFICATION AS THEORETICAL LEVEL FOR A STRUCTURAL DIFFERENCE BETWEEN FICTION AND NON- FICTION
}

\section{LA SIGNIFICACIÓN COMO NIVEL TEÓRICO PARA UNA DIFERENCIA ESTRUCTURAL ENTRE LA FICCIÓN Y LA NO FICCIÓN}

\author{
Miguel Amores Fúster \\ Universidad de Zaragoza
}

\section{ABSTRACT}

The expression of literary fiction is potentially unlimited. It could be said, like Searle, that potentially any text whatever can occur in fiction. By contrast, the contents of non-fictional discourses always have some kind of limits. Starting from this basic premise, this article will defend that the primary semiotic correlate that explains this difference can be found at the level of what Umberto Eco calls «signification» (that is, the culturally codified link that, within the sign, binds the planes of expression and content together). Thus, a theoretical structural difference between fiction and non-fiction is that in each case meaning is created following different signification logics. Whereas in non-fictional texts the signification link is governed by predetermined norms that arise from a series of real social and cultural interactions, in texts of literary fiction, which have no obligatory commitment to real world, this signification link is managed as if it were a potential in a virtually unlimited way. 
Keywords: Fictionality, signification, difference fiction-nonfiction, discourse.

\section{RESUMEN}

La expresión literaria ficcional es potencialmente ilimitada. Podría decirse, al modo de Searle, que potencialmente cualquier texto puede ocurrir en ficción. Sin embargo, los contenidos de los discursos no ficcionales siempre tienen algún tipo de límite. Partiendo de esta premisa básica, en este artículo se defenderá que el correlato semiótico primario que explica esta diferencia se encuentra en el nivel de lo que Umberto Eco entiende por «significación» (es decir, el vínculo culturalmente codificado que, dentro del signo, une plano de la expresión y plano del contenido). Así, una diferencia teórica estructural entre ficción y no ficción es que ambas crean sentido siguiendo lógicas de significación diferentes. Mientras que en los textos no ficcionales el vínculo significante se rige por normas predeterminadas que surgen de una serie de interacciones sociales reales, en los textos literarios ficcionales dicho vínculo se administra de forma potencialmente ilimitada como si se tratara de un potencial.

Palabras clave: Ficcionalidad, significación, diferencias ficción-no ficción, discurso.

Fecha de recepción 20 de julio de 2019.

Fecha de aceptación: 5 de agosto de 2019.

Cómo citar: Amores Fúster, Miguel, «Signification as theoretical level for a structural difference between fiction and non fiction», en Actio Nova: Revista de Teoría de la Literatura y Literatura Comparada, 3 (2019): 142-165.

DOI: https://doi.org/10.15366/actionova2019.3.007 


\section{INTRODUCTION}

For several decades now, numerous theoretical approaches have discouraged establishing a clear distinction between fictional and non-fictional texts. Or, at least, they recommend not to establish rigid and restrictive borders between literary fiction and fiction understood in its broadest sense, as a cross-cutting resource to all possibilities of human communication. From Pavel's critique of what he called «segregationist approaches» (1986: 11) to more recent pragmatic proposals (Walsh, 2007; Nielsen, Phelan, and Walsh, 2015), there is a certain tendency within fiction theory to dissolve the boundaries between literary fiction and the rest of communicative possibilities. Our goal in this article, however, is to defend the opposite position. Our goal is to demonstrate that, at least with respect to narrative literary fiction (I will leave aside poetry, theater and other types of non-literary fiction ${ }^{1}$ there is a structural difference between fictional discourse and the rest of communicative texts. This difference, as will be seen in the next few pages, is based on the potential infinity of fictional literary expression, which is absolutely exclusive to this communicative modality. We will defend that its theoretical trace can be first found in the primitive instance of human language, on the level that Umberto Eco calls «signification».

\section{THE POTENTIAL INFINITY OF FICTIONAL EXPRESSION}

As is well known, John Searle's article «The Logical Status of Fictional Discourse» (1975) has had a huge impact on fiction theory. Since its publication more than four decades ago with its central thesis of fictionality conceived in terms of pretended illocutionary acts, this text has generated hundreds of pages written by supporters and critics $^{2}$. However, there is a fragment of that article which expresses what in my opinion is one of the key points of fiction, and that, as far as we know, has received little theoretical attention. It is an incidental phrase, meant as a clarification of little importance, but which expresses one of the

\footnotetext{
${ }^{1}$ For reasons of clarity, in this article the term «fiction» will refer only to the specific fictional modality of narrative literary fiction unless stated otherwise.

${ }^{2}$ There are some authors extremely critical of Searle's thesis (Cohn, 1999: 117; Martínez Bonati, 1992: 61-69; Walton, 1990: 81-89; Doležel, 1998: 11). On the other hand, there are other authors who develop a pragmatic approach to fiction (Genette, 1993: 30-54; Pratt, 1977; Adams, 1985; Ohmann, 1971; Pavel, 1986: 43, and in a certain sense, Ryan, 1991: 64-65) who follow to a greater or lesser degree Searle's main theses, although they modify or even reformulate them.
} 
fundamental distinguishing characteristics of literary fiction. Searle writes this sentence within the framework of a broader argument. In it, Searle rejects the idea that fiction, in spite of not fulfilling any of the felicity conditions of speech acts, has a completely differentiated way of signification. That is to say, despite the fact that fiction violates practically each and every one of the pragmatic rules that govern communication, fictional singularity is not based on a clearly differentiated way of creating meaning with respect to the rest of the communicative possibilities. Searle writes:

That view is at least prima facie an impossible view since if it were true it would be impossible for anyone to understand a work of fiction without learning a new set of meanings for all the words and other elements contained in the work of fiction, and since any sentence whatever can occur in a work of fiction, in order to have the ability to read any work of fiction, a speaker of the language would have to learn the language all over again, since every sentence in the language would have both a fictional and a nonfictional meaning (Searle, 1975: 324).

The italicized phrase is vital to understand the radical uniqueness of fiction with respect to any other type of discourse. Although at first glance that phrase may seem trivial, it is actually quite the opposite, since it is precisely this radical and potentially infinite freedom of fictional expression that distinguishes it to a far greater extent than any other element from the rest of communicative modalities. Let us think about it for a moment. Would there be any other kind of discourse which this phrase could be applied to literally, to its ultimate consequences? Could it be said, for example, that any sentence whatsoever can occur in scientific, legal or religious discourses? Could it be said, even, that any sentence whatsoever can occur in what could be called everyday speech discourse? Apart from fiction, could we find any communicative modality in which any sentence could potentially occur? In our opinion, the answer is no.

In general, a discourse involves complex sets of norms that make it impossible for every possible phrase to have a place in it. It is hard to imagine that a sentence like «Excuse me, could you tell me where the nearest supermarket is?» could be part of a legal, scientific or religious discourse. Even the most informal types of discourse types have their own norms about what is suitable to say. Thus, it would be difficult to imagine a sentence like the following, «If two systems are in thermal equilibrium with a third system, they are in thermal equilibrium with each other», which corresponds to the zero principle of thermodynamics, in a daily conversation.

However, in fictional discourse, as Searle points out, every sentence imaginable 
could occur, at least potentially. There is no sentence that from the start and in itself could be considered inappropriate, unacceptable or even strange in a fictional text. Unlike the legal field, where a defect of form can annul an entire text, it is impossible to imagine a single sentence that would not have any place at all in a work of fiction, no matter the form of the sentence, its content or even the fact that it does not respect basic grammatical norms, as often happens in works like James Joyce's Finnegans Wake (1939). Unlike in the rest of communicative modalities, every sentence imaginable could potentially occur in a work of fiction.

But the uniqueness of fiction does not lie only in this ability to accommodate any sentence. This fact, in our opinion, would only be the consequence of a deeper theoretical circumstance. The potential infinite expression of fiction that Searle talks about translates, in our opinion, into the fact that any string of sentences (i.e., any text) can occur (could potentially occur) in fiction. The fundamental reason is that, with the exception of certain microfictions, the vast majority of fictional works are comprised of hundreds or even thousands of sentences, so the minimum unit of fictional analysis is the text. Thus, the potential infinity of fictional expression would imply not only that it easily has the capacity to accept sentences impossible to accommodate in any other communicative modality, such as the initial sentence of Finnegans Wake: «Riverrun, past Eve and Adam's, from swerve of shore to bend of bay, brings us by a commodius vicus of recirculation back to Howth Castle and Environs» (Joyce, 2012: 2); what the potential infinity of fictional expression really means is that it has a virtually unlimited capacity to accommodate any set of sentences, that is, any text.

The point is, could a text be imagined which had no place at all in a work of literary fiction? Are there any limits to the textual content of a fictional work? Are there any limits to the way it can create and combine any kind of sentences? In other words, is there any textual content that could be rejected a priori as capable of being part of a work of fiction?

In this case the answer would not be just «no», but something more complex. Of course, we are not attempting to say that any text, that literally anything, could be considered a work of fiction. In spite of the pragmatic approaches that consider fiction a cultural convention and therefore not essential and historically variable, a shopping list or a technical report on the state of a building would not in any case be considered a full work of fiction. The key point is that both contents, like any other ones imaginable, would be susceptible to forming part of a fictional text (or could be somehow integrated into it). That is, a work of 
fiction could incorporate without any problem a shopping list, a report on the state of a building and, potentially, any kind of content.

In this sense, the adverb "potentially» is hugely important. There is no doubt that it would be very rare to see certain types of content (the complete instructions of a DVD player, for instance) in a work of fiction. However, there is no textual content at all that could be excluded a priori and in a definitive way from being part of a work of fiction. Thus, not every single textual content could be considered fiction, but we could define fiction as that expressive modality with the ability to potentially accommodate every textual content imaginable.

To the extent that it is accepted that fictional contents do not have any a priori limitations in regard to form or content, that the only limitations are the writer's narrative skills and the reader's ability to understand the text, it seems inevitable to accept that any text can occur in a fictional work. Potentially, a fictional work can be about any subject and can be written in any style, and any limitation to this potentially absolute expressive freedom of fiction can only be understood as a form of censorship. Extreme experimental works such as the aforementioned Finnegans Wake or the no less singular La Disparition (1969) by George Perec could only be conceived this way. Besides, only under this premise could the normalization and systematization of the impossible fictional worlds carried out by the socalled «unnatural narratology» ${ }^{3}$ be assumed.

However, beyond these extreme cases, the potentially infinite fictional expression can manifest itself in any work. This is so not only because of the absolute potential freedom of fiction in regard to form and content. It is also because in works of fiction that do not aspire to an avant-garde status we can find a large variety of possibilities of meaning generation which in the rest of discourses tend to be more limited. This is manifested in the presence in numerous works of resources such as multiperspectivism, omniscient narration, alterations of the narrative order (flashbacks, flash-forwards, etc.), the massive use of dialogues, or the use in a literal sense of verbs that describe interior processes (feeling, thinking, etc.), which are known as a whole as «symptoms of fictionality» (Hamburger, 1977:

\footnotetext{
${ }^{3}$ According to Richardson, an unnatural narrative is «one that conspicuously violates conventions of standard narrative forms, in particular the conventions of nonfictional narratives, oral or written, and fictional modes like realism that model themselves on nonfictional narratives. Unnatural narratives furthermore follow fluid, changing conventions and create new narratological patterns in each work. In a phrase, unnatural narratives produce defamiliarization of the basic elements of narrative» (2011: 34). For a wider description of the concept, see Shang's article «Unnatural Narratology: Core Issues and Critical Debates» (2015).
} 
56-111; Schaeffer and Ducrot, 318-320; Rifaterre, 1990: 29-30; Hempfer, 2004: 309 et seq.; Gorman, 2008: 166-167).

As Ronen argues (1994: 79-80), these ways of creating meaning are not absolutely exclusive to fiction. But here what we want to highlight are the implications of the simultaneous presence of several of them in the same text. Thus, although a text such as a personal diary could use some of these resources, the simultaneous presence of several of them in the same text would be hardly possible in a non-fictional text and would be a sign of fiction's potential expressive infinity.

For all these reasons, and despite the fact that fiction shares many features with non-fictional discourses, the expressive resources of fiction are potentially unlimited. However, in the case of non-fiction, as will be seen in the following point, these expressive resources are always limited by their greater or lesser subjection to the real world. The key point is not just that this means that fictional expression is richer and more varied than nonfictional expression. The fact that potentially any text can occur in fiction and only some can do so in non-fiction ultimately implies that the former, unlike the latter, controls in a potentially unlimited way how it generates meaning, that is to say, the way it signifies.

\section{2. «REALITY DISCOURSES» VS «FICTION DISCOURSES»}

Now then, what does this imply exactly? What would be the exact theoretical implications of this potentially unlimited ability of fiction to generate meaning that does not occur in the rest of the communicative modalities? Our hypothesis is that this peculiarity of fictional expression has its origin in a differentiated mode of signification (see point 4. below). However, before attempting to demonstrate this hypothesis it is necessary to establish a distinction between what we call «reality discourses» and «fiction discourses». It is a difference that essentially corresponds to Doležel's distinction between «world-imaging texts» or «I-texts» and «world-constructing texts» or «C-texts» (1998: 24).

According to the Czech theorist, I-texts express states of things of a pre-existing world, so we can apply extensional values of truth and error to their contents. For example, a journalistic text is a clear example of an I-text because it talks about a certain state of things in a pre-existing world, the real world. And it is precisely the existence of this real world that allows us to establish values of truth and error based on the degree of coincidence between 
what is expressed in the text and its real referent. For example, if a piece of news said that Hillary Clinton won the US presidential elections of 2016, it would be false because there is no reference in our world that matches with that statement.

On the other hand, Doležel defines C-texts as those that, instead of expressing states of things in a pre-existing world, create a world through their enunciative display, so no truth or error values of an extensional type can be applied. This group would include texts ranging from scientific hypotheses (which do not express states of things of the real world, but possibilities that are projected in possible worlds) to fictional literary texts. According to Doležel, literary fiction texts are a type of C-texts. And he calls «textual poiesis» (1998: 23) this ability of C-texts to create worlds in their enunciative display instead of expressing preexisting states of things.

As we said, we mostly agree with these two great typologies of texts, as well as with the fact that fictional works are a type of C-texts. However, there is an element that in our opinion distinguishes works of fiction from the rest of C-texts in a decisive way. This concept could be called, for lack of a better phrase, the «margin of expression of unreality». By this we mean that both I-texts that refer to false contents (that is, lies) and non-literary fictional C-texts, such as scientific hypotheses or macroeconomic forecasts, have limits when they express contents that do not match with real world.

In the case of lies, this limit is determined by certain conditions of verisimilitude given by a real context. For example, if someone were late for an appointment because he got up late, he could say that his delay was due to traffic problems. In this case, the effectiveness of his lie (that is, the likelihood of being believed) would depend on a series of conditions derived from more or less empirical data of the real world, such as whether traffic jams are or are not common in that area. However, if that person says he arrived late because he was abducted by a UFO, then it is extremely unlikely that he would be believed.

Something similar occurs with non-fiction C-texts (scientific hypotheses, macroeconomic forecasts, etc.). In this case, and even though they do not express states of things in the real world but create possible worlds in logical terms (that is, they are the logical expression of states of things more or less susceptible of becoming real [see Ronen, 1994: 17-46]), their enunciation is still subject in many ways to real world. Thus, a more or less plausible scientific hypothesis would be that, according to the data available so far, some kind of microbial life could be found on a moon of Saturn. However, it would be impossible to accept as a serious scientific hypothesis that some kind of aliens dominate us in secret by 
controlling the minds of our rulers.

Scientific hypotheses and the rest of non-literary C-texts, despite creating worlds in their own enunciative display, are clearly bound by a series of conditions of verisimilitude and coherence dictated by the real world at a given moment and in a determined cultural community.

However, fictional enunciation would be unique for being potentially free of any commitment to the real world. Or put in another way, by deploying a potentially unlimited textual poiesis. It is true that some fictional realistic text typologies can limit the degree of unreality of a work of fiction. Moreover, it is no less true that there are certain general postulates of fictional comprehension, such as the «principle of minimal departure» (Ryan, 1991: 48-60 and Walton, 1990: 144-150), which in some way limit the unreality of a fictional text. But despite all this, fictional expression is potentially immune to any limitation or strict adaptation to the real world, as can be seen in fantasy genres or, to a greater extent, in the so-called «unnatural narratives».

It is as a function of this radical singularity of fiction with respect to any other type of communicative modality that we propose to distinguish between «reality discourses» and «fiction discourses». Reality discourses would encompass the set of I-texts and C-texts that do not belong to the category of literary fiction, that is, they encompass the set of texts whose enunciation would in some way be subject to the criteria of plausibility and to the limitations of all kinds imposed by the real world. This would include many kinds of non-factual and non-real contents, from simple lies to scientific hypotheses or economic forecasts. On the other hand, fictional discourses would be those whose margin of expression of unreality would be potentially unlimited because they create with virtually complete freedom the conditions of existence of the contents they express. These kinds of texts deploy a virtually unlimited textual poiesis, so they would not be bound in any way by the reality of our real world.

\section{LITERARY FICTION AS A TEXTUAL PHENOMENON OF SIGNIFICATION}

In many ways, the different existing theories of fiction could be considered as attempts to explain how the aforementioned fictional textual poiesis, potentially unlimited, functions. Take as a reference the scheme of triple differentiation between factual and 
fictional narratives proposed by Schaeffer (2013). The different semantic, pragmatic and syntactic approaches could be understood as descriptions of the radical singularity of fictional meaning generation.

Our hypothesis is that, in order to describe properly the potentially unlimited character of fictional expression, it is not enough to inquire into aspects related to the three classical divisions of semiotics established by Morris (1938: 6). Instead, a previous instance should be looked into, the signification or primal instance of the formation of the sign. Our hypothesis is that fictional specificity, the point at which its potentially unlimited expression and poiesis first emerge (and then deploy their corresponding semiotic, pragmatic and syntactic correlates), begins in the singular nature of the signification link in fictional texts.

Figure 1

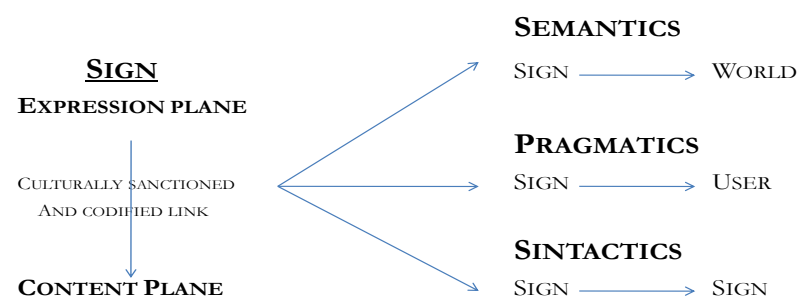

\subsection{SIGNIFICATION AND THE ARBITRARY NATURE OF THE SIGNIFICATION} LINK

Here «signification» will be understood in the sense given by Umberto Eco in his famous work $A$ Theory of Semiotics (1979). According to that author, signification is a codified and culturally sanctioned link that joins the two constituent functives of the semiotic function or sign, the «expression plane» and the «content plane» (1979: 48). For example, the signification link that constitutes the linguistic sign / fire/ is formed by the set of cultural conventions by which, in a concrete and culturally sanctioned code (in this case, the English language), the word «fire» (expression plane) refers to the concept fire (content plane). However, Eco underscores that the signification phenomenon happens not only at the level 
of the individual sign, but also in «vast portions of discourse» (1979: 4). That is, it could be said that there is a level of micro signification and a level of macro signification that would operate in a more complex way, in texts. This latter type of signification is the one that interests us because literary fiction, as we have said, is fundamentally a textual phenomenon.

In regard to this concept of signification, it is worth remembering the arbitrary nature of the link between the expression plane and the content plane of a sign. It is a circumstance that in the field of semiotics goes back at least to Saussure (1966: 65-71), and that would have as unequivocal proof the very wide verbal variety with which the different languages refer to identical referents. We say this because, ultimately, the fact that the link between the expression plane and content plane is arbitrary has resulted in the structural axiom that the linguistic sign is necessarily unable to predetermine the nature or exact meaning of the contents it expresses.

In order to try to explain this we will use an argument a contrariis. A good example is an alarm pheromone secreted by an insect and detected by another of the same species. Beyond the fact that this is a type of communication based on «signals» instead of «signs» (1979: 19-21) and that there can be mistakes in interpretation, what this way of communication certainly does is to presuppose the real nature of the perceived danger.

The insect that secretes the alarm pheromone may have detected the danger in a correct way, or maybe it was mistaken, and it is therefore a false alarm. It can also happen that the receptor insect correctly interprets such a pheromone and acts accordingly, or maybe it misinterprets the signal and acts erroneously. But from the point of view of the signification, the key point is that the mere fact of the secretion of an alarm pheromone implies that the communicational contents are absolutely real. In other words, communication through pheromones, beyond failures, misinterpretations or even deceptions, necessarily implies the factuality of the contents expressed. As a communicative element, the alarm pheromone implies the existence of an absolutely real and factual danger, without the possibility of double meanings, irony or fiction.

However, the aforementioned constitutive arbitrariness of the linguistic sign is exactly the opposite of this necessary identification between expression plane and content plane seen in the exchanges of signals of information through pheromones. This is what follows from Eco's famous axiom according to which any sign that can be used to tell the truth can be also used to lie (that is, that a linguistic sign is incapable of presupposing the factuality of its contents, let alone its true character) (1979: 6-7). In this same sense, it is 
possible to situate Derrida's reflection in the context of his argument with Searle (Derrida, 1988). According to the French theorist, with regard to speech acts, one cannot speak strictly about «serious» or «non-serious» uses of language since such considerations presuppose a stable and determined notion of context. And this is ultimately impossible since the notion of context is structurally variable (not «saturable») (Limited INC, 1988: 12). So, serious or nonserious uses of language cannot be determined with absolute certainty. That is why Derrida, contrary to Searle's opinion, defends that the sign itself is not predetermined to a serious use. A serious use is as consubstantial to the sign (an informative, factual and true phrase, such as «Paris is the capital of France») as another use considered not serious (a literary, fictional and empirically false phrase, such as «Once upon a time there was a world in which Rouen was the capital of France»).

There is nothing, therefore, that presupposes the truth, facticity, precision, property, etc., of a linguistic content. Beyond its literal denotation, it could have a figurative, ironic or metacoded meaning, or it could be the fruit of the incoherent chatter of a madman or a drugged person... or it could express a state of things of a fictional world.

Thus, in spite of all its possible defects and corruptions, in information exchanges of pheromones the signification link necessarily implies facticity, so they are unable to express fiction or any other non-serious language uses. However, in the case of linguistic signs, given that the expression-content link has an arbitrary character and can present a potentially infinite variability, chains of signs are in themselves just as focused on facticity as on fictionality. In short, the necessary (though not sufficient) condition of fiction is the arbitrary nature of the signification link. And this, in turn, necessarily results in sign's inability to predetermine in a necessary way the nature or exact meaning of the contents being expressed.

\subsection{Signification AT THE TEXTUAL LEVEL: DisCOURSE ACCORDING TO}

\section{FOUCAULT}

Now then, and always from the point of view of signification, if the human linguistic sign is such a poorly defined communicative entity, how is it possible that we understand each other? If in itself the sign does not presuppose the factuality or the truth of the content to which it alludes, how is effective communication possible, and more so taking 
into account that human interactions are usually based not on solitary signs, but on very long chains of signs, in texts? How is it possible not only that we normally know what our interlocutor is talking about, but above all in which exact terms he or she is doing it? Beyond the set of pragmatic norms that are generally taken for granted in the majority of communicative acts (Austin, 1955; Searle, 1969; Grice, 1967, etc.), the antidote to this fundamental indetermination of the chains of linguistic signs is what Van Dijk and Kintsch call «knowledge structures» (1983: 46-49).

With this concept the authors refer to all those conventionalized schemes that guide the way through which we understand large groups of signs in different communicative situations. There are numerous types of knowledge structures. The «scripts» (Schank and Abelson, 1977), for example, determine what can be expected in communicative terms in everyday life situations such as going to the dentist or going out to dinner. For written texts, Van Dijk uses the term «superstructure», which he defines as «conventionalized schemata which provide the global "form" for the macrostructural "content" of a text» (1980: 127). An example of a superstructure could be the set of conventional pre-comprehension frames that a scientific article invokes, and that are completely different from those of a news story or a novel.

In textual communication, perhaps the main knowledge structure is the discursive type. In this article, which explores fiction as a textual signification phenomenon, we have opted for Foucault's description of discourse in his work The Archeology of Knowledge (1969).

There is a reason for taking Foucault's conception of discourse instead of others that are more recent or specific to linguistics. And the reason is that it could be said that the French author, in spite of never using the term «signification» in the sense in which it is used here, assumes discourse as a predetermined way to signify. That is: Foucault conceives of discourse as a tremendously complex array of historically variable socio-cultural expressions and interactions that make a certain group of statements exist with a set of predetermined meaning properties. And this set of predetermined meaning properties starts, in semiotics terms, at the level of signification.

For Foucault, a discourse is not what common sense more or less dictates, that is, a set of statements related to the same topic, or pronounced under the same point of view, or expressed by a specific group of people authorized to do so, or a group of texts which shares a series of stylistic features and conceptual categories. A discourse is all these things, but the enormous complexity and heterogeneity of the concept requires a series of specific 
categories that the author constructs in The Archeology of Knowledge. According to Foucault, a discourse is the «principle of dispersion and distribution» of a specific set of statements (1972: 107). And the key point to this definition is the specific sense that the author gives to the term «statement».

According to Foucault, a statement cannot be identified with culturally wellestablished and discrete units (in the mathematical sense of the term «discrete») such as a grammatical sentence, a logical proposition or a speech act. Instead of corresponding to any of these prefixed categories, a statement is «a function that is exercised vertically in relation to these various units» (in reference to the phrase, the logical proposition and the speech act) (1972: 86). So the Foucaultian statement is a semiotic «function of existence» (1972: 86) that makes any chain of signs exist with a set of predetermined meaning properties. For Foucault, a statement is not something that can be assimilated or runs parallel to a sentence, a logical proposition or a speech act. A statement is what makes them be; what makes the sentence, logical proposition or speech act function as such. In this way, the statement is «a function that crosses [within language] a domain of possible structures and units and that makes them appear, with concrete contents, in space and time» (1972: 87).

Consider medical discourse as an example. According to Foucault, medical discourse is not just what is said about medicine, or what doctors say, or a set of statements expressed in a certain style in which we can find terms and concepts such as «muscular elongation» or «asepsis». The author considers that, precisely because medical discourse is partially all these things, it is also a differentiated enunciative economy, a concrete way of inserting the chains of signs in the sense that goes far beyond the linguistic field. Thus, the medical discourse provides itself, through a series of processes and historical evolutions, with a series of proper values of truth and error; it establishes a certain order of social interactions (role of the patient, role of the doctor, role of the health authorities); it also constitutes a singular system of relations with other discourses. (In conjunction with the legal discourse, for instance, it creates objects such as sick leave), etc.

For all these reasons, the difference between finding the word «infarct» in a medical record or in the headline in a sports chronicle is not only semantic. It is not just that in one case it refers to a real health situation and in the other case it is a metaphorical use to express a great emotion. The real difference is that, in the case of the medical record, the word «infarct» involves a series of processes to establish values of truth and error, protocols and obligations for the patient and doctor, legal and labor implications, etc., which do not take 
place in the second case.

Foucault's theorizing about this enunciative level is extensive and complex. It includes concepts such as «referential» (1972: 91) or «enunciative function» (1972: 88-105) which cannot be explained here for reasons of space. However, what we want to emphasize here is that, in Foucault's thought, the discourse or singular mode of establishing a set of predetermined meaning properties for a group of statements goes far beyond the linguistic field and is constituted as a differentiated dynamic of manifestations and socio-cultural interactions. And the key point is that these socio-cultural interactions are completely real. So, regardless of whether a statement or set of statements that belong to a particular discourse can be false, what always will be real is the set of socio-cultural interactions that insert those false contents into the general economy of meaning.

Thus, a false legal statement can be expressed («ignorance of the law exempts one from compliance of the same»), but this does not eliminate the vast set of real socio-cultural interactions that the concept «legal discourse» implies. The statement's contents could be false according to certain lie and truth values established by legal discourse, but the entire structure of meaning generation, based on a series of real historical and cultural interactions, remains fully valid. As is the case with «reality discourses», (which, as was seen in point 3, also covered lies and unproven hypotheses), it could be said that the socio-cultural interactions which determine the specific mode of meaning generation of a discourse are «reality interactions». The way they create meaning will always have a correlate of real sociocultural processes, an unavoidable subjection to real world.

\subsection{THE STRUCTURAL DIFFERENCE BETWEEN FICTIONAL AND NON-} FICTIONAL DISCOURSES: SIGNIFICATION AS A NORM VS. SIGNIFICATION AS MANAGING A POTENTIAL

Before proceeding to explain the fundamental thesis of this article it is necessary to make a brief review of what has already been pointed out. First, based on a seemingly trivial sentence by Searle, we have established the premise that a fundamental structural difference between fiction and nonfiction is that the former has a potentially unlimited (textual) expression, while in the latter the expression always has some kind of limit. Then we argued that this potential absence of limits of fictional expression can be translated into a potentially 
unlimited textual poiesis, in the sense that fiction is capable of creating its own structures of meaning with virtually total independence from the real world. Finally, in the different sections of point 4 we have tried to defend that the primary semiotic correlate of this singularity of fictional expression is at the level of signification, understood in the way of Umberto Eco. In 4.1 it was affirmed that the necessary (though not sufficient) condition of fiction is the inability of the signification link to clearly and unambiguously determine the nature of the content alluded to. And in 4.2 it was explained that the antidote against this radical indetermination of the chains of signs are the predetermined and conventionalized understanding schemata called «knowledge structures». In the case of textual communication, the most important of these knowledge structures are the different discourse types. And in order to link this with our initial premise, which conceives literary fiction as a textual signification phenomenon, we chose the Foucaultian conception of discourse. According to Foucault, a discourse is a predetermined way of signifying. Discourses are described as differentiated systems of predetermining the way in which, within the texts, expression planes allude to content planes. Finally, the different discourses, beyond the linguistic field, are based on a series of historically variable and completely real socio-cultural interactions.

Now that the fundamental premises of the argument have been summarized, the fundamental thesis of this article can finally be explained. And this is none other than that the potentially infinite expression of fiction necessarily demands a singular mode of signification. As we have seen, non-fictional discourses or «reality discourses» signify according to a series of norms that ultimately depend on some kind of systematic subjection to real world. Thus, the real world stands as a premise and a basic guiding principle of its signification. But in fiction, this dependence on the real world is much more uncertain. It is true that fictional worlds, by virtue of certain general principles such as mimesis or the aforementioned «principle of minimal departure», take the real world as their base. But the way in which its signification is subject to the real world can never be adjusted to a systematic scheme.

Thus, the difference between fiction and nonfiction is not the difference that exists between a discourse with systematic rules of signification (an article of inorganic chemistry) from another which does not have them (a science-fiction novel). The issue does not fit into an axis of normative rigidity-normative flexibility. What really points toward the infinite potential expression of fiction is that it exceeds the normative framework of the rule. Fiction, despite 
taking the real world as a foundation, does so in such a non-systematic way that it is not possible to capture it through rules. The fact that every fictional work establishes with potentially absolute freedom

a) its own architecture of modal reality systems (Doležel, 1998: 113-132), and

b) its own pragmatic communicational structures (Adams, 1985: 9-14),

prevents its signification from being explained only by norms.

But if fictional signification cannot be explained through norms alone, how can it be explained? Our proposal is that fictional signification is not governed by more or less predetermined norms, however flexible they may be. Fiction simply manages the signification link as if it were a potential. In fiction there is no real world from which to obtain restrictive meaning construction rules, so it has to construct in each text (and potentially, in each extract of each text) the way it means. What ultimately denotes the fact that any text whatever can potentially occur in a work of fiction is that the foundational expression-content link does not have a predetermined model. Instead, it must be managed flexibly as a potential of meaning generation.

Figure 2

- Sign IN NON-FiCTION DisCOURSE

EXPRESSION SIGNIFICATION

CONTENT

PREDETERMINED RULES

- SigN IN FICTIONAL DisCOURSE

EXPRESSION SIGNIFICATION CONTENT 
According to this scheme, fictional texts do not signify in a predetermined way, like reality discourses do. They are able to potentially manage at every moment (and potentially in an unlimited way) how they signify. By this, we mean not only polysemy, or the fact that fictional texts have a greater semantic richness than non-fiction texts in terms of a greater presence of connotations or metaphorical meanings. What we really mean to say is that the worlds created by the fictional poiesis do not only have a real existence in ontological terms, but they also lack that dense accumulation of real social interactions that articulate meaning creation in non-fiction discourses.

It is true that fiction, through basic principles like mimesis or a series of schemata of meaning prefiguration such as literary genres, do not build their meaning from scratch. In fiction there are certain predetermined signification frames that are always in force. However, the potentially absolute independence of fiction with respect to the real world makes its rules of signification structurally unstable. That is why fictional signification is not ruled by norms, which will always be exceeded, and works instead as a potential that has to be managed.

Let us look at an example taken from a not particularly avant-garde work, Michel Houellebecq's novel Les Particules élémentaires (1998). Even beyond the fact that the novel has a science-fiction theme or that it uses typically fictional resources such as multiperspectivism, the fictionality of the text would be explained through the variety of signification levels it has. Thus, there are two major poles of signification in the work. The first, the story declared as fictional (that is, metafictional) of a biographer of the future who tells the story of the two protagonists, the half-brothers Michel and Bruno. And the second, the texts of the prologue and the epilogue. In these, someone who is apparently the same historian of the future narrates in a supposedly factual way the events that enabled the genetic manipulations that made possible a new humanity. In both main instances of signification, moreover, there are important variations. In the first case, for example, passages like the following one, in which the experience of Bruno in a swinger club is narrated,

With his five-inch cock and his inability to maintain an erection between orgasms (he had never really been able to sustain one for any length of time, except perhaps as a teenager, and the time between ejaculations had grown considerable since then: he wasn't getting any younger), Bruno wasn't really in his element in such places (Houellebecq, 1998: 202).

Contrast with metatextual reflections such as the following: 
The story of a life can be as long or as short as the teller wishes. Whether the life is tragic or enlightened, the classic gravestone inscription marking simply the dates of birth and death has, in its brevity, much to recommend it. However, in the case of Martin Ceccaldi, it seems appropriate to set his life in a socioeconomic context, to say less about the individual than the society of which he is symptomatic. Carried forward by the sweep of history and their determination to be a part of it, symptomatic individuals lead lives which are, in the main, happy and uncomplicated. A couple of pages are sufficient to summarize such a life (1998: 20).

On the other hand, the (fictional) historical narration of the prologue, in which the narrator theorizes about the nature of the paradigm changes that from time to time occur throughout human history:

Metaphysical mutations - that is to say radical, global transformations in the values to which the majority subscribe- are rare in the history of humanity. The rise of Christianity can be cited as an example (1998: 4).

Ends with what looks like an epic poem:

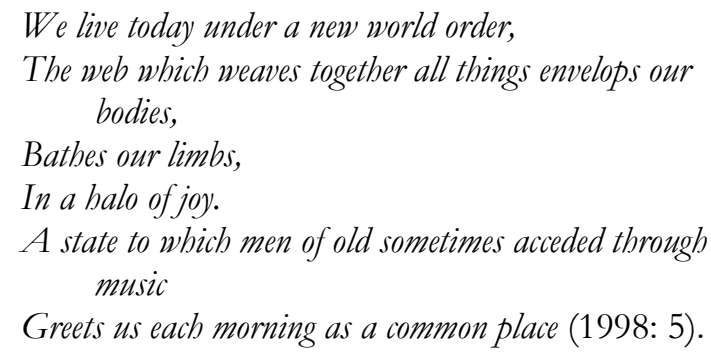

These are isolated examples taken from a specific work. However, it would not be difficult to find similar examples in any work of fiction. Novels and short stories enable multiple meaning planes in which this plurality and heterogeneity of signification positions are common and overlap each other without any difficulty, which allows them easily to assume any textual content. Again, one could posit whether any textual content would be radically incompatible with fictional enunciation. And again, the answer would be, potentially, no.

\section{CONCLUSIONS}

Searle wrote the phrase that served as the starting point to this article $(«[\ldots]$ and 
since any sentence whatever can occur in a work of fiction») when developing an argument about a possible differentiated signification in fiction. Indeed, for Searle, the problem of how it is possible for fiction to be intelligible and have meaning despite breaking the rules that govern illocutionary acts takes the form of a significant «paradox»:

We might put the problem in the form of a paradox: how can it be both the case that words and other elements in a fictional story have their ordinary meanings and yet the rules that attach to those words and other elements and determine their meanings are not complied with: how can it be the case in "Little Red Riding Hood" both that "red" means red and yet that the rules correlating "red" with red are not in force?" (Searle, 1975: 319).

The author's answer to this question is well known. It is not that the pragmatic norms that link the expression plane («red») with concept plane (the concept of red) are not in force in fiction. It is just that, according to the author, in fiction signification works in terms of illocutionary pretense. Fictional speech acts are not essentially different from nonfiction speech acts. The former just pretends to have the genuine illocutionary force of the latter.

As we have seen throughout this article, our proposal also starts at the basic level of signification. However, the main premise defended here is that the singularity of fictional signification cannot be translated in terms of rules capable of predetermining how a text signifies. The basic motive, as we have seen, is the potentially unlimited character of fictional signification. How could the potential infinity of fictional expression be represented in the form of a normative predetermination scheme? How could the fact that any text whatever is likely to occur in fiction be systematized through rules? Where could one find, in fiction, a vast series of real and historically variable cultural interactions, which, according to Foucault, are the necessary premises of all discourse?

As seen in figure 2, the reason that explains the absolute potential of fictional expression is its potentially absolute control over the way it signifies. Or to put it more simply: in every text, and potentially in every single passage of every text, fiction has the ability to decide in what terms it creates meaning. And this, in its primary semiotic correlate, is identified with the signification mode. In fiction, signification is not a set of rules that predetermine the way in which, at the textual level, the expression plane alludes to the content plane, as it is in the rest of discourses. Instead, in fiction, such a link is handled as a potential that can be manipulated in a potentially unlimited way. If any text whatever is likely 
to occur in fiction it is just because fictional texts, free from virtually any link to the real world, have a potentially unlimited control over the way they signify.

According to a phrase commonly attributed to Truman Capote, the problem with living outside the law is that you no longer have its protection. Something similar could be said about the difference between fictional signification and the signification of the rest of discourses. As seen in 4.1, the expression-content signification link is arbitrary. And as has been defended in 4.2, a discourse is a way of controlling (always at a textual level) such arbitrariness in order to prefigure the general sense of a series of chains of signs. Fiction, by managing the primary signification link as potential, would simply assume that consubstantial semiotic instability and would create its textual contents with potentially total freedom. This would place fiction outside the ordinary discursive laws, which fix the conditions according to which a text signifies in terms of a series of attachments to the real world. However, given that fiction lives outside these laws, it also lives (in signification terms) outside its protection. The fictional signification link will be always unstable, or what is the same: fiction will never be able to fully determine in what terms, in its texts, expression planes allude to content planes. 


\section{WORKS CITED / BIBLIOGRAFÍA}

Adams, Jon-K. (1985): Pragmatics and Fiction, Amsterdam/Filadelfia, John Benjamins Publishing Company.

Austin, John (1955): How to do Things with Words, Oxford, Clarendon Press.

Nielsen, Henrik; James Phelan; Richard Walsh (2015): «Ten Theses about Fictionality», in Narrative 23, (1): 61-73.

Cohn, Dorrit (1999): The Distinction of Fiction, Baltimore, Johns Hopkins University Press.

Derrida, Jacques (1988): Limited Inc., Evanston (Illinois), Northwestern University Press.

Doležel, Lubomír (1998): Heterocosmica. Fiction and Possible Worlds, Baltimore: Johns Hopkins University Press.

Ducrot, Oswald; Jean-Marie Schaeffer (1995): Nouveau dictionnaire encyclopédique des sciences du langage, Paris: Seuil.

Eco, Umberto (1979): A Theory of Semiotics, Bloomington, Indiana University Press.

Foucault, Michel (1972): The Archaeology of Knowledge, translated from French by A. M. Sheridan Smith, New York, Pantheon Books.

Hamburger, Käte (1977): Die Logik der Dichtung. Stuttgart: Klett-Cotta.

Hempfer, Klaus (2004): «Some Problems Concening a Theory of Fiction (ality)», in Style, 38 (3): 302-324.

Houellebecq, Michel (2000): The Elementary Particles, translated from French by Frank Wynne, New York, Alfred Knopf.

Genette, Gérard (1993): «Acts of Fiction», in (1993): Fiction \& Diction, Ithaca (New York), Cornell University Press: 30-54.

Gorman, David (2008): «Theories of Fiction», in Herman, David, Jahn, Manfred and Ryan, Marie-Laure (eds.) (2008): Routledge Encyclopedia of Narrative Theory, New York, Routledge: 163-167.

Grice, Herbert (1967): «Logic and Conversation», in Cole, Peter and Morgan, Jerry (eds.) (1967): Syntax and Semantics, Vol III: Speech Acts, New York: Academic Press: 41-58. Joyce, James (2012): Finnegans Wake, Oxford, Oxford University Press.

Martínez Bonati, Félix (1992): «El arte de escribir ficciones», in (1992): La ficción narrativa (su lógica y ontología), Murcia: Murcia University Press: 61-69.

Morris, Charles (1938): «Foundations of the Theory of Signs», in Neurath, Otto, Carnap, Rudolph and Morris, Charles (eds.) (1938): International Encyclopedia of United Science, 
vol. I, no. 2, Chicago: Chicago University Press: 1-59.

Ohmann, Richard (1971): «Speech Acts and the Definition of Literature», in Philosophy \& Rhetoric 4 (1): 1-19.

Pavel, Thomas (1986): Fictional Worlds, Cambridge, Harvard University Press.

Pratt, Mary Louise (1977): Towards a Speech Act Theory of Literary Discourse, Bloomington (Indiana), Indiana University Press.

Riffaterre, Michael (1990): Fictional Truth, Baltimore, The Johns Hopkins University Press.

Richardson, Brian (2011): «What is Unnatural Narrative Theory?», in Alber, Jan and Heinze, Rüdiger (eds.) (2011): Unnatural Narratives, Unnatural Narratology, Berlin, De Gruyter: 23-40.

Ronen, Ruth (1994): Possible Worlds in Literary Theory, Cambridge: Cambridge University Press. Ryan, Marie-Laure (1991): Possible Worlds, Artificial Intelligence and Narrative Theory, Bloomington (Indiana): Indiana University Press.

Saussure, Ferdinand (1966): Course in General Linguistics, translated from French by Wade Baskin, New York, McGraw-Hill.

Schaeffer, Jean-Marie (2013): «Fictional vs. Factual Narration», in Hünh et al. (eds.) The Living Handbook of Narratology, Hamburg, Hamburg University Press: http://www.lhn.unihamburg.de/article/ fictional-vs-factual-narration (last visit: 17/06/2019)

Schank, Roger and Robert Abelson (1977): Scripts, Plans, Goals and Understanding. An Inquiry into Human Knowledge Structures, Hillsdale (New Jersey), Erlbaum.

Searle, John (1969): Speech Acts, Cambridge, Cambridge University Press.

Searle, John (1975): «The Logical Status of Fictional Discourse.», in New Literary History 6 (2): 319-332.

Shang, Biwu (2015): «Unnatural Narratology: Core Issues and Critical Debates», in Journal of Literary Semantics 44 (2): 169-194.

Van Dijk, Teun (1980): Macrostructures. An Interdisciplinary Study of Global Structures in Discourse, Interaction and Cognition, Hillsdale (New Jersey), Erlbaum.

Van Dijk, Teun; Kintsch, Walter (1983): Strategies of Discourse Comprehension, New York, Academic Press.

Walsh, Richard (2007): The Rethoric of Fictionality. Narrative Theory and the Idea of Fiction, Columbus (Ohio), Ohio University Press.

Walton, Kendall (1990): Mimesis as Make-Believe, Cambridge, Harvard University Press. 
SOBRE EL AUTOR

\section{Miguel Amores Fúster}

Miguel Amores (Madrid, 1986) es licenciado y doctor en Teoría de la Literatura y Literatura Comparada por la Universidad de Salamanca. Sus investigaciones se centran en la ficcionalidad como fenómeno literario transversal, en las sinergias entre teoría de la literatura y biopolítica y en el escritor francés Michel Houellebecq. Entre sus publicaciones más destacadas se encuentra el libro Ficción. Anatomía de un potencial infinito (Visor, 2018) y el artículo "La paradoxe du reality: une réflexion sur la posture littéraire de Michel Houellebecq" (Çédille, 2019). Ha trabajado como investigador en el Instituto de Estudios Medievales y Renacentistas y de las Humanidades Digitales (IEMYRhd), asociado a la Universidad de Salamanca, y en la actualidad es profesor de literaturas hispánicas en la Universidad de Zaragoza.

Contact information: Correo electrónico: amoresfuster@unizar.es 